\title{
Review studies of Neighborhood Sustainability Assessment tools
}

\section{Gulala Abdalqadir Aziz}

City planning department, Engineering college, Sulaymani Polytechnic University . Sulaimani, Kurdistan region, Iraq.

Email: gulala.abdulqar@spu.edu.iq

\section{ABSTRACT:}

Urbanization due to population growth has negative environmental impact. The sustainable developments of the city and neighborhoods becomes as essential requirement. For this purpose, in the last few years several Neighborhood Sustainability Assessment tools have been developed and used around the world. The aim of this research is comprehensive review of the used neighborhood sustainability assessment tools in the literature and compares the assessment criteria among the tools. The systematical review method is used in this study in order to determine the development, progress, and future direction of this emerging topic. The result of this study shows an overview of neighborhood sustainability assessment tools in the context of annual publications and journal publishers, authors main contribution, published research by countries, common neighborhood sustainability assessment tools in literature, and literature findings. This paper recommends potential research area for future researchers and policymakers of neighborhood and residential sustainable design.

Key Words: Neighborhood Sustainability Assessment (NSA) tools, Sustainable Development, LEED-ND, BREEAM Communities, and CASBEE-UD. 


\section{INTRODUCTION:}

Urbanization and city expansion have negative environmental impact including sprawl, increasing automobile dependence, increasing energy needs, water, material, gas emission, and impact on biodiversity (Shen, 2012,P.24). Studies show that $75 \%$ of the global energy consumption and $80 \%$ of the total GHG ( Green House Gas) emissions are consumed by cities (Komeily and Srinivasan, 2016, P.876). More attention has been drawn to sustainability and particularly urban communities as a result of the various iterations of continuously emerging global issues such as climate change and urbanization. It is now considered as a critical and important framework due to the extended range of concerned issues including degradation of environment, depletion of resources and issues related to socio-economic status (AlQahtany, Rezgui and Li, 2013, P.5).

After the establishment of UN World Commission and development report (the Brundtland Commission) in 1987, development has become an important term in the vocabulary of politicians, administrators, and planners. Brundtland Commission's report, the 1992 conference on Environment and Development in Rio de Janeiro, and the following works of the United Nation's Committee on Development and Environment have interpreted sustainable development as the combination of ethical standards of welfare, distributing and democracy while acknowledging that the ability of nature in absorbing human-made intrusions and pollution have limits (Sharifi and Murayama, 2015,P.5). The Brundtland Commission's report has one entire chapter that discusses and describes sustainable development. Brundtland has tried to define sustainable development in a way that will meet the needs of both present and future generation s ("WCED," 1987). In the practice of urban planning, it is agreed that urban planning has four dimensions: social, economic, institutional and environmental dimension. Development cannot be considered as sustainable development unless these four dimensions are addressed (Sharifi and Murayama, 2013,P.5).The definition given indicates that sustainable development ensures that residents in both rich and poor countries, now and in the future will have their essential needs met (Sharifi and Murayama, 2013,P.5). It is imperative to implement this concept without endangering the natural 
resources and systems on which life is reliant. In addition, when it comes to processing the decision, democracy and legitimacy are two necessary and important key qualities that must be present(Næss, 2009,P.504).

Neighborhoods are the largest most populated fabric of cities and their basic planning unit. Accordingly, they have the largest environmental footprint in cities and the lion share of resources and energy consumptions (Sharifi and Murayama, 2014). Scholars argue that neighborhoods have a big role in achieving sustainability for cities (Yigitcanlar, Kamruzzaman and Teriman, 2015,P.3; Sharifi et al., 2016a,). Achieving sustainability for new and/or existing neighborhoods cannot be done without criteria and assessments. For this purpose, a number of Neighborhood Sustainability Assessment (NSA) tools have been developed and used around the world in the last few decades.

Since the emergence of NSA tools, a growing number of studies used these tools to measure the sustainability of neighborhoods in different cities across the world. The variation among these tools and their assessment criteria make their selection and applicability to different context questionable. While some studies reviewed some of the existing NSA tools used in a different part of the world, the literature still lacks comprehensive studies that investigate and compare the findings from the use of these tools. Such investigation will inform and guide new research in selecting appropriate existing NSA tool(s) and assessment criteria to another context.

The aim of this research is comprehensive review of the used NSA tools in the literature and compares the assessment criteria among the tools. The systematically reviews method are used in this study in order to determine the development, progress, and future direction of this emerging topic.

As part of this review, this paper examines the methodologies and findings of previous NSA tools related studies. The findings from this paper highlight the gaps in the NSA tools literature and guides future research in this area of study. 


\section{OVERVIEW OF NSA TOOLS}

The idea of sustainable development arose subsequently after the birth of the awareness of local and regional environmental problems. With sustainability being considered as the ultimate goal, demand on using indicators for urban monitoring and regulation is increasing continuously in highly populated and urban areas ( $\mathrm{Li}$ et al., 2009,P.135).

Having a reliable tool(s) for the purpose of measuring sustainability is becoming a necessity for the identification of processes that are not sustainable. Such tool(s) will also equip designers with information, methods, and measures to predict the quality of their designs and monitor their impacts (Sharifi and Murayama, 2015,P.3). Additionally, they will facilitate Evidence-Based decision making (Komeily and Srinivasan, 2016). Standardized measurements for neighborhood sustainability also help with better management of environment, policy making, local participation, advocacy, consensus building, analysis and research in new development of neighborhoods (Komeily and Srinivasan, 2016). Certain organizations like national Green Building Councils (GBC) and Building Research Establishment (BRE) have invented frameworks and tools for assessing sustainability (Sharifi and Murayama, 2014,P.244).These frameworks were initially developed for sustainable development of individual buildings. While these tools measure some aspects of neighborhood sustainability in neighborhoods, they fail to account for many other bigger scale dimensions of neighborhoods and built environments (Sullivan, Rydin and Buchanan, 2014,P.4). This is mainly because these frameworks had taken an inductive approach towards sustainability, which believes that sustainability can be obtained "by working at the margins" instead of taking into consideration the complexity of building-urban relationships (Komeily and Srinivasan, 2015,P.34). As a result, adopting some of these tools at neighborhood sustainability assessment scale gain more momentum (Sharifi and Murayama, 2015). Neighborhood Sustainability Assessment (NSA) tools evaluate and contrast the functionality and performance of sustainability in a given neighborhood against a set of certain themes and criteria. These tools, therefore, provide guidelines in assessing a neighborhoods' progress towards sustainability and indicate the successfulness of the neighborhoods in achieving sustainability goals (Sharifi and Murayama, 2015,P.4). 
NSA tools are also used for assessing urban communities, district sustainability, neighborhood sustainability, and sustainable communities ( Komeily and Srinivasan, 2015,P.42). As of today, a number of assessment tools have been specifically designed to evaluate sustainability in neighborhoods solely. For example, LEED-ND from USA, BREEAM Communities from UK, CASBEE-UD from Japan, ECC from USA, HQE2R and Eco city from the European Union, SCR from Australia, QSAS from Qatar, Green Mark for Districts from Singapore, NSF from New Zealand, HK-BEAM from Hong Kong, Eco Effect from Sweden, Eco Profile from Norway, and Escale from France are some of the wellknown tools (Yigitcanlar, Kamruzzaman and Teriman, 2015,P.2572).

In 2007, United States Green Building Council (USGBC), Congress for New Urbanism (CNU), and the National Resources Defense Council (NRDC), came together to found LEED-ND as a voluntary tool for guiding sustainable neighborhood development. Many projects around the world have adopted LEED-ND as a guiding framework for neighborhood development plans. Assessment criteria of LEED-ND are categorized into five themes: "smart growth and linkages", "neighborhood pattern and design", "green infrastructure and buildings", "innovation and design process", and "regional priority credit"(Shari and Murayama, 2014,P.245)

BREEAM communities is developed in 2011 by BRE Global, BREEAM Communities ad-vocates the consideration of sustainability principles at the earliest stage of the design process. The 2011 version, divides the assess-ment criteria into nine separate themes: "climate and energy", "resources", "place shaping", transport and movement", "community", "ecology and biodiversity", "business and economy", "build- ings", and "innovation" (Shari and Murayama, 2014,P.245). CASBEE-UD is a collaborative product of Japan Green BuildingCouncil (JaGBC), and Japan Sustainable Building Consortium (JSBC). It was developed in 2006 and its 2007 version has been used in this paper. CASBEE-UD applies a unique methodology for assessment in which environmental efficiency is calculated by dividing the environmental quality (QUD) within the site boundary to environmental load (LUD) on the spaces beyond the site boundary. The criteria for environmental quality are divided into three themes of "naturalenvironment", "service functions for the designated area", and "contribution to the local community". Similarly, "environmental impact on microclimates, façade, and landscape", "social infra- structure", and "management of the local environment" are three themes used for assessing the environmental load (Shari and Murayama, 2014,P.246). 
The following table summarizes a list of tools that are used to assess and certify neighborhood sustainability in redevelopment plans along with their country of creation ( Komeily and Srinivasan, 2015,P.42).

Table1: List of NSA tools (Sharifi, 2013; Komeily and Srinivasan, 2015,P.42)

\begin{tabular}{|c|c|c|}
\hline NSA tools name & Developer(s) & Country/region \\
\hline "LEED-ND" & $\begin{array}{c}\text { US Green Building } \\
\text { Council (USGBC), } \\
\text { New-Urbanism- } \\
\text { Congress (CNU), } \\
\text { Council-of-Natural } \\
\text { Resources-Defense } \\
\text { (NRDC). }\end{array}$ & USA \\
\hline "BREEAM Communities" & BRE Global & UK \\
\hline $\begin{array}{l}\text { "CASBEE-for-Urban } \\
\text { Development" }\end{array}$ & $\begin{array}{l}\text { Japan-Sustainable- } \\
\text { Building-Consortium } \\
\text { (JSBC), and Japan- } \\
\text { Green-Building- } \\
\text { Council (JaGBC) }\end{array}$ & Japan \\
\hline "DGNB-for-Urban"- & $\begin{array}{l}\text { German Council of } \\
\text { Sustainability }\end{array}$ & Germany \\
\hline "Districts" & $\begin{array}{l}\text { Green-Building- } \\
\text { council-of-Australia }\end{array}$ & Australia \\
\hline $\begin{array}{l}\text { "Green-Star-communities- } \\
\text { Star-Community-Index" }\end{array}$ & $\begin{array}{c}\text { International Council } \\
\text { for local Environmental } \\
\text { Initiatives (ICLEI), } \\
\text { USGBC , National } \\
\text { League of Cities, } \\
\text { Center for American } \\
\text { progress }\end{array}$ & USA \\
\hline $\begin{array}{l}\text { "GSAS/QSAS } \\
\text { Neighborhoods" }\end{array}$ & $\begin{array}{l}\text { Gulf Organization for } \\
\text { Research and } \\
\text { Development }\end{array}$ & Qatar \\
\hline "Green Mark for Districts" & $\begin{array}{c}\text { Authority of } \\
\text { Construction and } \\
\text { Building }\end{array}$ & Singapore \\
\hline $\begin{array}{l}\text { "Neighborhood } \\
\text { Sustainability Framework" }\end{array}$ & Beacon-Pathway-Ltd & NZ \\
\hline
\end{tabular}




\section{Method:}

This paper systematically reviews NSA tools literature to determine the development, progress, and future direction of this emerging topic. As part of this review, the paper maps the NSA tools based on their frequency of use by literature, case studies location, time of publication, and type of research papers. This review also determines active scholars and countries in this field to inform and guide new future research. While different studies have been conducted on NSA tools, including review studies on developer, criteria, indicators of NSA tools and research papers on application of these tools in a different context, but none of these studies collected, summarized, compared, and synthesized these studies together.

To determine NSA tools publications, the paper first identifies the most common academic journals that publish on neighborhood sustainable assessment tools. Powerful and credible academic databases and search engines such as ScienceDirect, Scopus, and Google Scholar were used to determine the targeted papers. ScienceDirect is one of largest research database which has an ability to search accurately and conveniently filter the results by year, type of article, and publication title. Scopus was also selected due to its ability to cover most databases of research publication in different areas such as engineering, management, business, and accounting. Google scholar was used in order to search the remaining targeted papers that are not covered by two other research engines. For the searches in these databases and search engine, keywords such as "(sustainability * or sustain) AND (Neighborhoods OR district OR community) AND (evaluation OR assessment) AND (tools* OR criteria* OR measurements* OR indicator* OR frameworks* OR rating system))" were used.

The automated search was followed by a manual review to determine papers that are: mainly focused on neighborhood sustainable assessment tools (NSA) and neighborhood sustainable development, and papers published in international journals and conference proceedings. Non-academic papers, book reviews, magazine articles, and industry reports were excluded. 


\section{RESUlT AND DISCUSSION:}

The searches and filtering resulted in a total of 27 journal papers to be reviewed manually and analyzed further. As part of the manual review, the papers were categorized based on the year of publication, publisher, author main contribution, and countries contribution, common NSA tools in literature, NSA tools paper type, and NSA tools literature findings. The review also provided an opportunity to determine active scholars in this area of research. The following section summarizes the findings.

\subsection{Overview of annual publications and journal publishers:}

Figure 1 shows that a few published papers can be seen in 2009, 2010, and 2011. It illustrates that less attention has been paid to NSA tools. Increasing trend was seen in publishing papers. For example, in 2018 records the largest number of published papers. Interests in NSA tools research was grown in the past few years. During that period, NSA tools were published mostly in sustainability, energy, planning, and architecture as appeared in Fig2. The chosen research articles from 2009 to 2019 were published in 12 international academic Journals. Figure2.Shows the published articles in each journal. While almost half of papers were published in Sustainable Cities and Society (SCS). This amount of published paper was followed by Sustainability, Ecological indicator, and Ecological Procedia respectively.

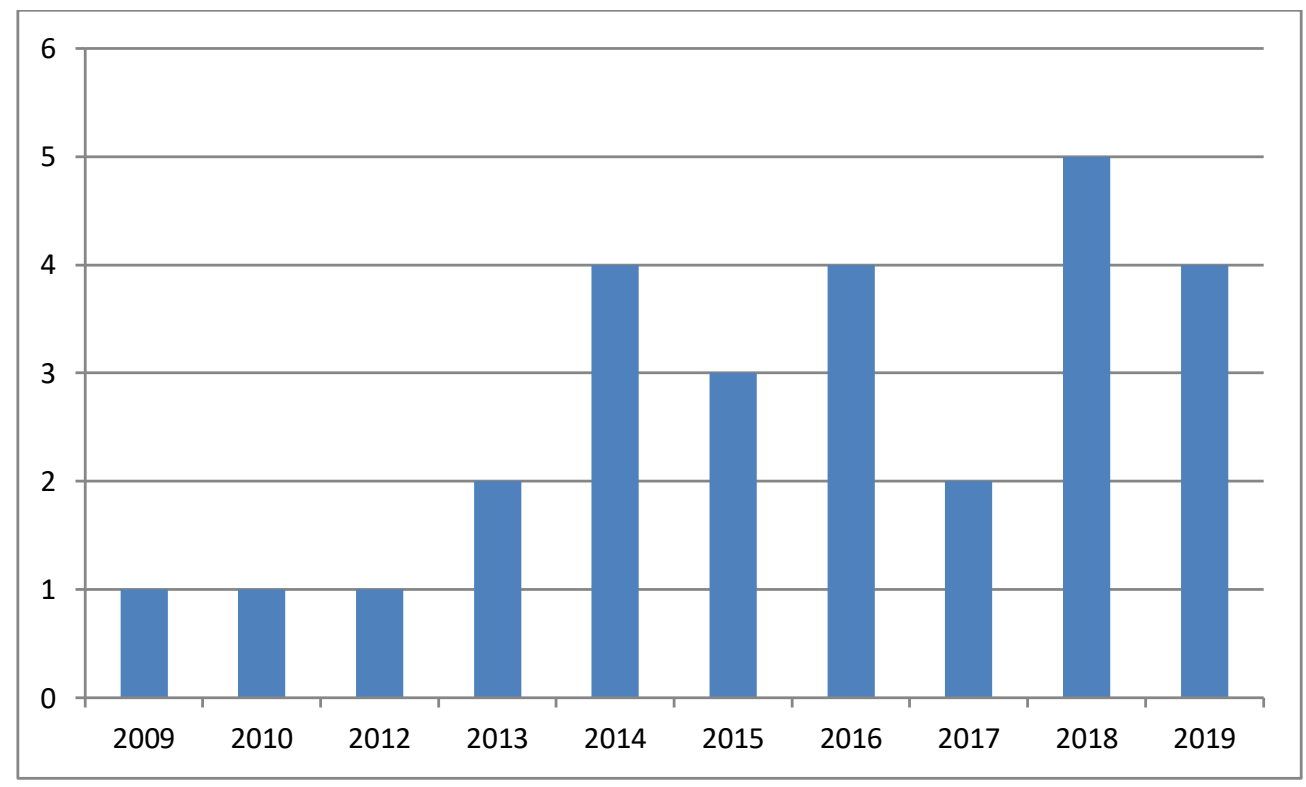

Figure 1: Published papers per year 


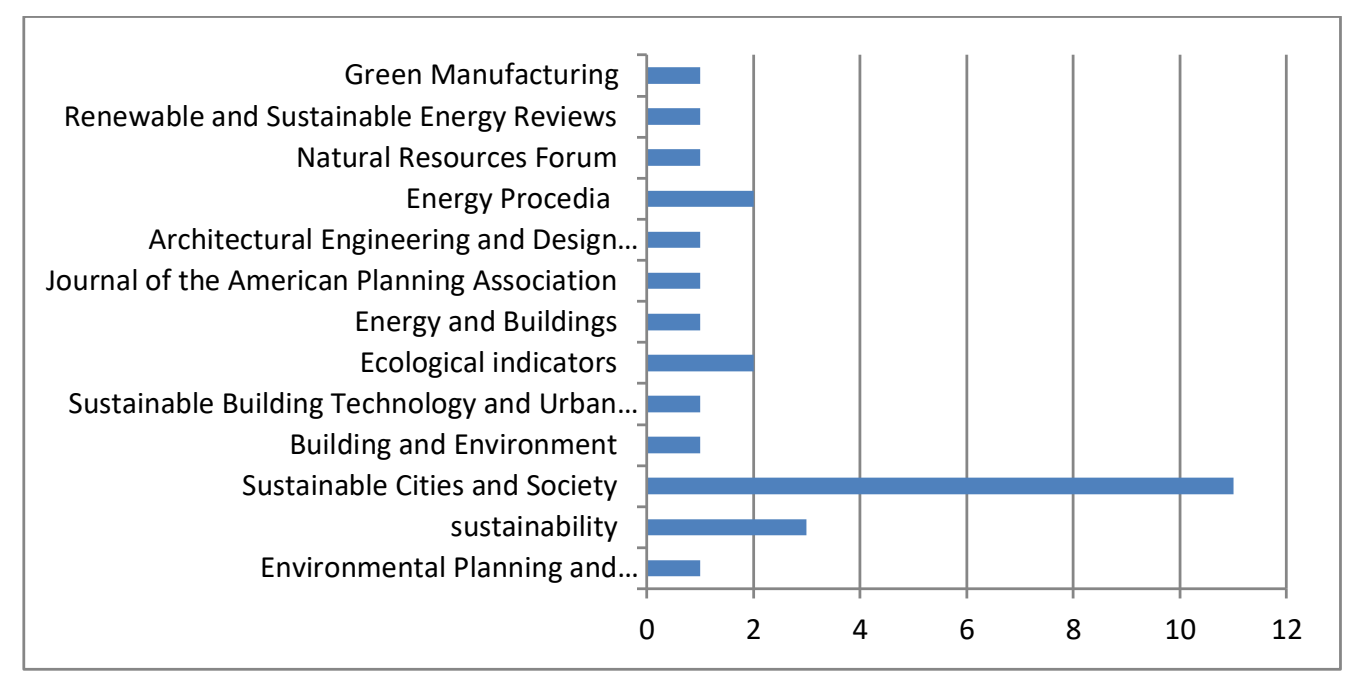

Figure 2: NSA tools Journal publishers

\subsection{Authors main contribution:}

Howard formula was used in order to determine active contributors in multi-author articles. Based on assumptions of the real contribution of an author in multi-authored paper, the formula was founded by Howard in 1987(Tsai, 2014,P.2770) The formula shows more contribution of first author compared to second author and second from third and so on (Tsai and Wen, 2002; Ke et al., 2010; Osei-kyei and Chan, 2015; Li, Chen and Wang, 2017,P.1078).

$$
\text { Score }=\frac{1.5^{n-1}}{\sum_{i=1}^{n} 1.5^{n-i}}
$$

Where $\mathrm{n}$ refers to the number of authors of the paper and it is the order of each author. When the formula was applied one point was given for each publication. Regardless of authors number. Therefore, the one point was divided into corresponding parts for each writer by the formula. Table2. Present A detailed score distribution for authors founded on the formula. 
Table 2. Contribution Score per an author in multi author papers.(Tsai and Wen, 2002; Ke et al., 2010; Osei-kyei and Chan, 2015; Li, Chen and Wang, 2017,P.1O78)

\begin{tabular}{|c|c|c|c|c|c|}
\hline \multirow{2}{*}{$\begin{array}{c}\text { Number of } \\
\text { authors }\end{array}$} & \multicolumn{5}{|c|}{ Order of authors } \\
\cline { 2 - 6 } & 1 & 2 & 3 & 4 & 5 \\
\hline 1 & 1 & & & & \\
\hline 2 & 0.6 & 0.4 & & & \\
\hline 3 & 0.47 & 0.32 & 0.21 & & \\
\hline 4 & 0.42 & 0.28 & 0.18 & 0.12 & \\
\hline 5 & 0.38 & 0.26 & 0.17 & 0.11 & 0.08 \\
\hline
\end{tabular}

Table 3 shows the highest contribution by high score and the lower score of the scholars. Scholars' contribution in single author and first author in multi authorized articles were calculated based on Howard formula and table 1. The results showed that in these publications most authors appeared only one time. As demonstrated, the most active author was Ayyoob Sharifia from Nagoya University due to his contribution in two single-author papers and two first authors in multi-author article. This is followed by Ali Komeily from University of Florida. While other scholars' contribution score is between 0.47 to 1 .

Table 3: Main contribution of authors

\begin{tabular}{|c|c|c|c|c|c|}
\hline Author & $\begin{array}{c}\text { NO. } \\
\text { appearan } \\
\text { ce }\end{array}$ & $\begin{array}{c}\text { Sole } \\
\text { author } \\
\text { appearanc } \\
\text { e }\end{array}$ & $\begin{array}{l}\text { First author } \\
\text { appearance }\end{array}$ & Score & Affiliation \\
\hline Ayyoob Sharifia & 4 & 2 & 2 & 3.2 & Nagoya University \\
\hline Ali Komeily & 2 & & 2 & 1.2 & University of Florida \\
\hline W.L. Lee & 1 & 1 & & 1 & $\begin{array}{c}\text { The Hong Kong } \\
\text { Polytechnic University }\end{array}$ \\
\hline Ajay Garde & 1 & 1 & & 1 & $\begin{array}{l}\text { University of } \\
\text { California }\end{array}$ \\
\hline $\begin{array}{c}\text { Jubril Olakitan } \\
\text { Atanda }\end{array}$ & 1 & 1 & & 1 & $\begin{array}{c}\text { Cyprus International } \\
\text { University }\end{array}$ \\
\hline Te-I Albert Tsai & 1 & 1 & & 1 & $\begin{array}{c}\text { Chinese Culture } \\
\text { University }\end{array}$ \\
\hline Ayotunde Dawodu & 2 & & 2 & 0.94 & $\begin{array}{c}\text { he University of } \\
\text { Nottingham Ningbo }\end{array}$ \\
\hline Eeva Säynäjoki a & 1 & & 1 & 0.6 & Aalto University, \\
\hline András Reith & 1 & & 1 & 0.6 & $\begin{array}{l}\text { ABUD Engineering } \\
\text { Ltd }\end{array}$ \\
\hline Tan Yigitcanlar & 1 & & 1 & 0.47 & $\begin{array}{c}\text { Queensland University } \\
\text { of Technology }\end{array}$ \\
\hline sing the feasible & 1 & & 1 & 0.47 & $\begin{array}{l}\text { temperature function } \\
\text { for a long-term }\end{array}$ \\
\hline Ali AlQahtany & 1 & & 1 & 0.47 & Cardiff University \\
\hline
\end{tabular}




\begin{tabular}{|c|c|c|c|c|}
\hline Xiaonan Zhang 1 & 1 & 1 & 0.47 & $\begin{array}{c}\text { The University of } \\
\text { Salford, }\end{array}$ \\
\hline Joana Pedro & 1 & 1 & 0.47 & $\begin{array}{c}\text { Technology and Policy } \\
\text { Research }\end{array}$ \\
\hline Qi Zhang & 1 & 1 & 0.47 & $\begin{array}{c}\text { The Hong Kong } \\
\text { Polytechnic University }\end{array}$ \\
\hline $\begin{array}{l}\text { Tseliso Moroke } \\
\text { Carel }\end{array}$ & 1 & 1 & 0.47 & North- West university \\
\hline Vivian W.Y. Tam & 1 & 1 & 0.42 & $\begin{array}{l}\text { Western Sydney } \\
\text { University }\end{array}$ \\
\hline $\begin{array}{l}\text { Carmen Díaz } \\
\text { López }\end{array}$ & 1 & 1 & 0.42 & University of Granada \\
\hline Ali Karji & & 1 & 0.42 & $\begin{array}{c}\text { Pennsylvania State } \\
\text { University }\end{array}$ \\
\hline Scott Cloutier & 1 & 1 & 0.38 & $\begin{array}{c}\text { Arizona State } \\
\text { University }\end{array}$ \\
\hline Husnain Haider, & 1 & 1 & 0.38 & Qassim University \\
\hline Xabat Oregi & 1 & 1 & 0.38 & $\begin{array}{c}\text { Tecnalia Corporacion } \\
\text { Tecnologica }\end{array}$ \\
\hline
\end{tabular}

\subsection{NSA tools research by countries :}

As appeared in table 4 that 22 first authors are represented from 15 different countries or areas. NSA tools papers are leading by the United State of America which is contributing almost double of the UK and four folded of other countries. This is followed by United Kingdom, China, and Australia. It can be concluded that most of papers came from developed countries which being counted $\% 85$ of papers as shown in figure 3. Although achieving sustainability is global issue, a little attention has been paid in developing countries.

Table 4: Main counties contribution to NSA tools

\begin{tabular}{|c|c|}
\hline Country & Frequency of contribution by authors \\
\hline USA & 4 \\
\hline UK & 2 \\
\hline China & 2 \\
\hline Australia & 2 \\
\hline Spain & 2 \\
\hline Japan & 1 \\
\hline Cyprus & 1 \\
\hline Taiwan & 1 \\
\hline Finland & 1 \\
\hline Hungary & 1 \\
\hline Italy & 1 \\
\hline Portugal & 1 \\
\hline Hong Kong & 1 \\
\hline South Africa & 1 \\
\hline Saudi Arabia & 1 \\
\hline Total & 22 \\
\hline & \\
\hline & \\
\hline
\end{tabular}




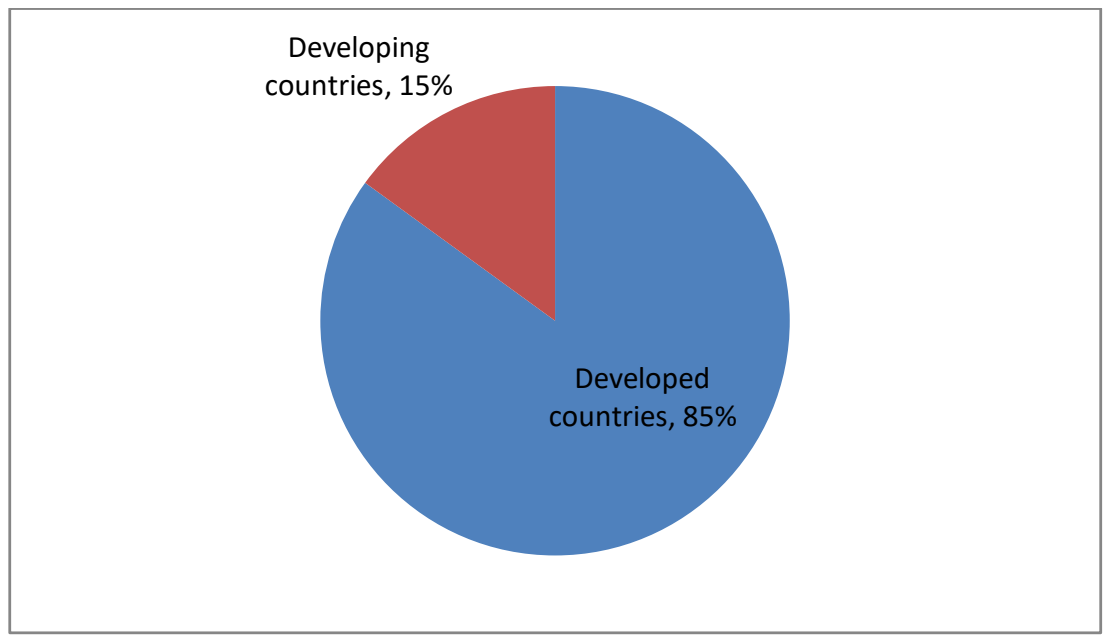

Figure 3: NSA tools developed and developing countries contribution

\subsection{Common NSA tools in literature :}

Table 5 illustrates that 12 of 27 papers have used LEED-ND. It is followed by BREEAM Communities and CASBEE-UD. It can be concluded that these three tools have global influences. Some times more than one tool was used in one paper. That is why totals frequency scores more than 27.

Table 5: common NSA tools in literature

\begin{tabular}{|c|c|c|}
\hline NSA tools & Frequency & Percentage \\
\hline LEED-ND & 12 & 44 \\
\hline BREEAM Communities & 9 & 25 \\
\hline CASBEE-UD & 9 & 25 \\
\hline DGNB-UD & 1 & 3 \\
\hline Chinese scheme ESGB & 1 & 3 \\
\hline
\end{tabular}

\subsection{NSA tools paper type}

The reviewed papers were classified into two types including case study and literature review. Based on their method that they have used, the $\% 56 \%$ of papers used critical review. While $\& 44 \%$ of papers have utilized a case study. 


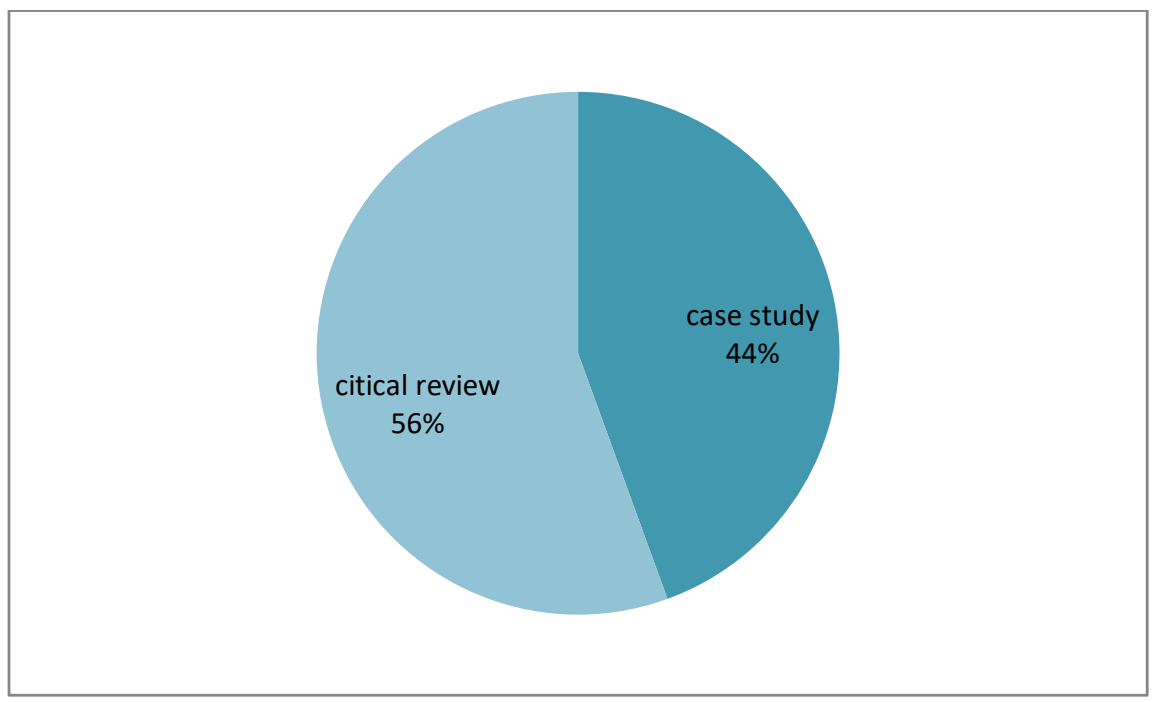

Figure 4: NSA tools paper type

\subsection{NSA tools literature findings}

The different scope of NSA tools papers was presented in table 6. The researches were divided into four categories of research area and findings.

Table 6: Scope of papers

\begin{tabular}{|c|c|l|}
\hline Scope & $\begin{array}{l}\text { Number of } \\
\text { publications }\end{array}$ & Publications \\
\hline $\begin{array}{c}\text { NSA tools review (comparison of } \\
\text { existing tools) }\end{array}$ & 10 & $\begin{array}{l}\text { (Garde, 2009), (Cloutier } \text { et al., 2018), (Komeily } \\
\text { and Srinivasan, 2015), (Tam } \text { et al., 2018), (András } \\
\text { Reith and Orova, 2016), (Lee, 2013),(López, } \\
\text { Carpio and Martín-morales, 2019), (Karji et al., } \\
\text { 2019),(Dawodu, Cheshmehzangi and } \\
\text { Akinwolemiwa, 2018), }\end{array}$ \\
\hline NSA tool Evaluation and case studies & 6 & $\begin{array}{l}\text { (Sharifi and Murayama, 2015), (Sharifi and } \\
\text { Murayama, 2014), (Säynäjoki et al., 2012), } \\
\text { (Ghellere, Devitofrancesco and Meroni, 2017), } \\
\text { (Oregi } \text { et al., 2016), }\end{array}$ \\
\hline NSA tools development & 5 & $\begin{array}{l}\text { (Dawodu, Cheshmehzangi and Akinwolemiwa, } \\
\text { 2018),(Chhipi-shrestha } \text { et al., 2017), (Yigitcanlar, } \\
\text { Kamruzzaman and Teriman, 2015), (Moroke, } \\
\text { Schoeman and Schoeman, 2019), (Atanda, 2018) }\end{array}$ \\
\hline $\begin{array}{r}\text { Different movements of neighborhood } \\
\text { sustainability }\end{array}$ & & $\begin{array}{l}\text { (Sharifi } \text { et al., 2016b), (Komeily and Srinivasan, } \\
\text { 2016),(Pedro, Silva and Pinheiro, 2018), (Tsai and } \\
\text { Wen, 2002),(Zhang } \text { et al., 2018), (Zhang, Cheng } \\
\text { and Wu, 2010) }\end{array}$ \\
\hline
\end{tabular}

- In the scope of NSA tools review (comparison of existing tools)

Scholars argued that existing NSA tools have different historical background, developer, categories, criteria, and indicators. in addition, they found that differences and similarities could be seen in criteria and indicator measurements 
under an umbrella of the same sustainability goals. In target papers, existing NSA tools were reviewed in different aspects including historical background, developer, categories, criteria, and indicators. General comparison is basic information NSA tools including historical background of tools, developers, certification types and schemes. The historical background of NSA tools is described, publication the years and revision of the existing NSA tools. The institutions or organizations which developed, operated and updated the NSA tools are called developers. For instances, LEED was built by Green Building Council (USGBC) from U.S.in 2009, and BREEAM was found by the Building Research Establishment (BRE) from UK in 2011. NSA tools classification rating is assessed with score levels. For example, there are four levels of certification for LEED-ND including Certified, Silver, Gold or Platinum. While BREEAM rating tool's certification process for developments starts with a rating of Pass is counted from $25-39 \%$ of maximum credits, Good is 40 - 54\%, Very Good is 55 - 69\%, Excellent from 70 - $84 \%$ and Outstanding from 85 - $100 \%$. In category comparison, sometimes categories are phrased as "themes," "assessment scope" or "sustainability coverage." This is a broad area of sustainability achievement. Similarities and important differences exist in the categories of NSA tools(Komeily and Srinivasan, 2015). For example, LEED-ND can be categorized into the following: "linkages and smart growth, "design and pattern of neighborhood" "buildings and green infrastructure", " design process and innovation", and "credit of regional priority". While BREEAM was divided into 8 categories: "Resources (RES)", "Climate and Energy (CE)", "Place Shaping (PS)", "Transport (TRA)", "Community (COM)", "Ecology and Biodiversity (ECO) Business (BUS) and Buildings (BLD)". In term of review of indicators, for example, the LEED-ND rating system is made up of 12 essential requisites that need to be met before the process of certification of neighborhood development. Five of the requisites belong to "Smart Location and Linkage category", three Belong to "Neighborhood Design and Pattern" and belong to "Buildings and Green Infrastructure". Once the requisites are met, we can freely choose credits from all four categories of assessment that together constitute 45 credits, it can be obtained up to 106 points in international projects. The certification level starts from basic and will require a minimum of 40 points, the next higher level is Silver; 50 points, then gold; 60 points, and finally the highest level which is platinum and it requires 80 points. Guidelines for meeting the essential requisites and reaching high levels of LEED-ND certification are explained in great detail, alongside in-depth manifestation of different methods and ways of meeting the criteria for 
different types of development (USGBC, 2009). NSA tools have used Different indicators and benchmarks in their assessment framework. For example, BREEAM Communities and LEED-ND have different methods to calculate connectivity. LEED-ND measures density with a number of intersections in the development in order to facilitate pedestrian movement. The BREEAM Communities consider direct connection between main routes of developments in order to provide direct lines of streets.

- In scope NSA tool Evaluation and case studies

Some scholars applied these tools on case studies from different countries in order to evaluate NSA tools applications in different contexts. They found that NSA tools have limitation to adapt to different contexts due to irrelevant some criteria and indicators in local context. For example, LEED-ND, which is NSA tools by united states of America, has an indicator to measure compact development. This indicator of compact development measures by residential density which determines 25 dwellings per one hectare for any development. While Asian and European countries have higher residential density compared to the American countries. It is concluded that this European and Asian country already has more than 25 dwellings per hectare. Another example is walkability indicator. It can be seen a similar argument for walkability measurement in LEED-ND tool. This indicator determines that building facades must be far 8 meters from the property line of the street. This measurement scale is suitable for American. While this indicator is irrelevant in Japan due to that Japanese typical house are close to the property line.

- In the scope of NSA tools development

Scholars criticized that existing NSA tools are not applicable internationally due to limitation of local context adaptation. For this reason, some researchers in literature developed existing NSA tools. Developing existing NSA tools was proposed in previous researchers. Challenges and opportunity of NSA tools measurements were studied to be developed internationally applicable. The main justification for developing a new assessment tool is local characteristics, especially in developing countries. For this reason a mixture of local and international experts was involved in order to develop existing NSA tools. Providing more dependable production to inform decision-makers were considered in developing tools. The Delphi method was used in developing NSA tools. 
- In the scope of different movements of neighborhood sustainability

Scholars argue that different movements appear in history of neighborhood. These movements have different contribution of neighborhood sustainability. Neighborhood scale is essential to achieve sustainable planning development. Different planning movements of neighborhood emerge since the early twentieth century. These neighborhood planning movements are "Garden city", "Neighborhood unit", "Modernism", "NAEO traditionalism", and "Eco urbanism". Scope of principles of these movements becomes broader over time. The Eco urbanism movements have the broadest scope compared to other recent movements. In addition, Eco urbanism gives emphasis to contribute neighborhoods significantly in global environmental changes. Policymakers and planners are recommended to see Eco urbanism as an opportunity to build sustainable and resilient neighborhood.

Furthermore, researchers in literature argue that a gap between theory and action in neighborhood planning is existed due to several reasons. The most repeated criticism that planners are over-dependence on physical, technological, and changing urban form. While they do not care about control of changing and behavioral social outcome. Planners and decision-makers were recommended to avoid using physical and technical solutions to social problems. 


\section{CONCLUSION AND RECOMMENDATION}

Cities and societies face environmental, social, and economical serious challenges due to urbanization, global warming, population growth, limited natural resources, and increasing gas emissions. Researchers and planners argue that sustainable development is an urgent need to city. For this reason neighborhood as the largest component of city must be developed sustainably(Sharifi et al., 2016a,P.4). regarding neighborhood sustainable development, the first action is to assess sustainability level of neighborhood(Yigitcanlar, Kamruzzaman and Teriman, 2015,P.2572). For this purpose, a few years ago some international NSA tools were recognized internationally, for example LEED-ND from USA, BREEAM Communities from UK, and CASBEE-UD from Japan.

Although different studies of NSA tools are available in the literature. There is no comprehensive study that investigates and compares the findings of NSA tools in literature. This paper is a comprehensive systematic review of NSA tools studies. 27 papers were reviewed including the year of publication, publisher, author main contribution, and countries contribution, common NSA tools in literature, NSA tools paper type, and NSA tools literature findings. The results show that contributions of authors are different and most studies are in developed countries. Some journals have most publication of NSA tools papers. In addition, the USA and UK tools are most popular in literature. Furthermore, different types of NSA tools papers could be seen in literature. NSA tools have different criteria and indicators for the same sustainability goals. Also, they have limitation to adapt in different context. For this reason, existing NSA tools in literature were developed in some aspects. This paper recommended that researchers and policymakers who work on neighborhood and residential sustainable design might use developed form of the NSA of existing NSA tools. In addition, future study should develop NSA tools comprehensively to cover all dimensions of sustainability. Developing countries need more studies of NSA tools compared to the developed countries. In addition, the best tools to be applied globally are developed NSA tools in literature. 


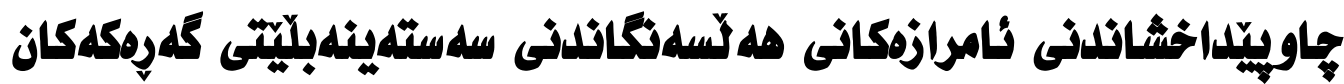

كَولآله عبدالقادر عزيز

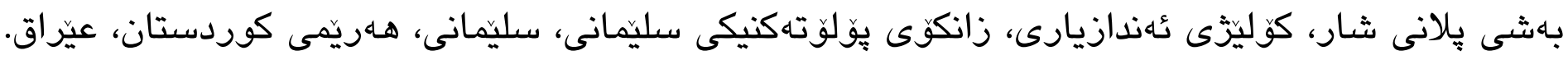

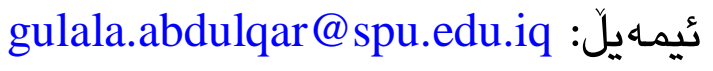

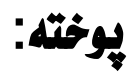

فراوان بوونى شارهكان بههوى كهشهى دانيشتوانهوه كاريكهرى نهينى زينكهيى هليه. سهستهينهليّتى كهرهكهان و

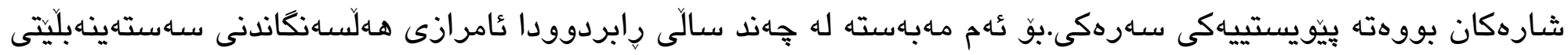

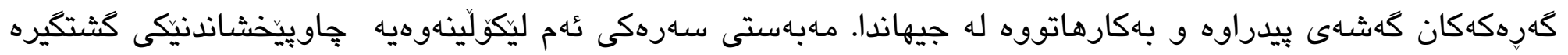

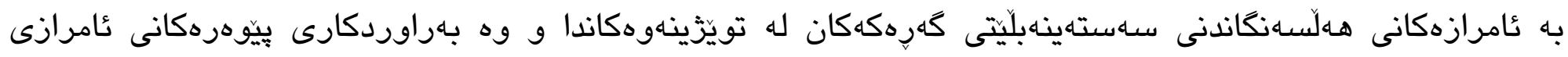

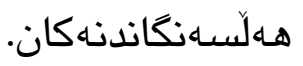
شيّوازى جاوييداخشاندنى سيستهماتيكى بهكارهاتووه بو دياريكردنى كهشه و ئاراستهى داهاتووى ئهم بابهته. ئهنجامى

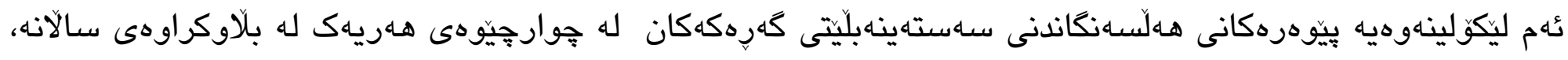

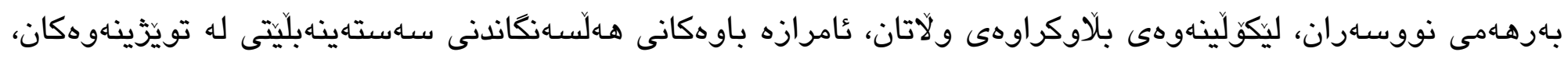

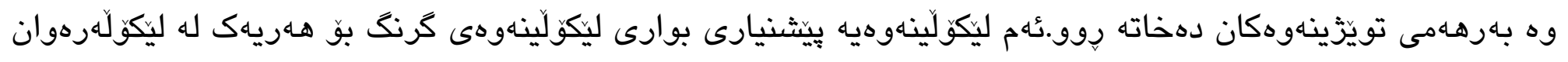
و برياردهرانى بوارى ديزاينى سهستهينهلّ بو كهرهك و شوينى نشينكهكان دهات.

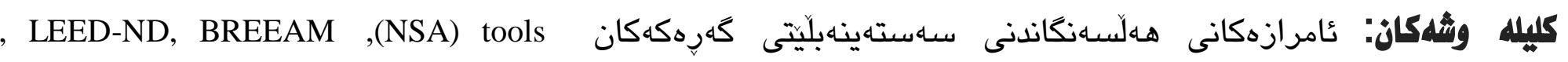
.Communities, and CASBEE-UD 


\section{REFERENCE:}

AlQahtany, A., Rezgui, Y. and Li, H. (2013) “A proposed model for sustainable urban planning development for environmentally friendly communities," Architectural Engineering and Design Management, 9(3), pp. 176-194. doi: 10.1080/17452007.2012.738042.

András Reith and Orova, M. (2016) “Do green neighbourhood ratings cover sustainability?,” Ecological Indicators.

Elsevier Ltd, 23(2), pp. 573-575. doi: 10.1016/j.ecolind.2014.09.005.

Atanda, J. O. (2018) “PT SC,” Sustainable Cities and Society. Elsevier B.V. doi: 10.1016/j.scs.2018.09.023.

Chhipi-shrestha, G. et al. (2017) "Sustainability Assessment Framework for Small-sized Urban Neighbourhoods: An Application of Fuzzy Synthetic Evaluation,” Sustainable Cities and Society. Elsevier B.V. doi:

10.1016/j.scs.2017.09.031.

Cloutier, S. et al. (2018) “Toward a holistic sustainable and happy neighborhood development assessment tool : A critical review of relevant literature,” Ecological Indicators. Elsevier, 89(2017), pp. 139-149. doi:

10.1016/j.ecolind.2018.01.055.

Dawodu, A., Cheshmehzangi, A. and Akinwolemiwa, B. (2018) "PT SC," Sustainable Cities and Society. Elsevier B.V. doi: 10.1016/j.scs.2018.05.033.

Garde, A. (2009) "Sustainable by design?: Insights from U.S. LEED-ND Pilot Projects," Journal of the American Planning Association, 75(4), pp. 424-440. doi: 10.1080/01944360903148174. 
Ghellere, M., Devitofrancesco, A. and Meroni, I. (2017) “ScienceDirect ScienceDirect Urban sustainability neighborhoods Lombardy Assessing the feasibility of using the heat Milanese forecast temperature function for a district heat demand," Energy Procedia. Elsevier B.V., 122, pp. 44-49. doi: 10.1016/j.egypro.2017.07.310.

Karji, A. et al. (2019) "Assessment of Social Sustainability Indicators in Mass Housing Construction : A Case Study of Mehr Housing Project,” Sustainable Cities and Society. Elsevier, 50(2017), p. 101697. doi:

10.1016/j.scs.2019.101697.

Ke, Y. et al. (2010) "Research Trend of Public-Private Partnership in Construction Journals,” (2009).

Komeily, A. and Srinivasan, R. S. (2015) “A need for balanced approach to neighborhood sustainability assessments : A critical review and analysis," Sustainable Cities and Society. Elsevier B.V., 18, pp. 32-43. doi: 10.1016/j.scs.2015.05.004.

Komeily, A. and Srinivasan, R. S. (2016) "What is Neighborhood Context and Why does it Matter in Sustainability Assessment?,” Procedia Engineering. Elsevier B.V., 145(December), pp. 876-883. doi: 10.1016/j.proeng.2016.04.114.

Lee, W. L. (2013) “A comprehensive review of metrics of building environmental assessment schemes,” Energy and Buildings. Elsevier B.V., 62, pp. 403-413. doi: 10.1016/j.enbuild.2013.03.014.

Li, A. Y., Chen, X. and Wang, X. (2017) “A review of studies on green building assessment methods by comparative analysis," Energy \& Buildings. Elsevier B.V. doi: 10.1016/j.enbuild.2017.04.076.

Li, F. et al. (2009) "Landscape and Urban Planning Measurement indicators and an evaluation approach for assessing urban sustainable development : A case study for China 's Jining City," 90, pp. 134-142. doi:

10.1016/j.landurbplan.2008.10.022. 
López, C. D., Carpio, M. and Martín-morales, M. (2019) “A comparative analysis of sustainable building assessment methods," Sustainable Cities and Society. Elsevier, 49, p. 101611. doi: 10.1016/j.scs.2019.101611.

Moroke, T., Schoeman, C. and Schoeman, I. (2019) “Ac ce p te d us cr t," Sustainable Cities and Society. Elsevier B.V. doi: 10.1016/j.scs.2019.101433.

Næss, P. (2009) “Urban Planning and Sustainable Development,” (2013), pp. 37-41. doi: 10.1080/0965431012004987.

Oregi, X. et al. (2016) "Sustainability assessment of three districts in the city of Donostia through the NEST simulation tool.” doi: 10.1111/1477-8947.12104.

Osei-kyei, R. and Chan, A. P. C. (2015) "ScienceDirect Review of studies on the Critical Success Factors for Public Private Partnership ( PPP ) projects from 1990 to 2013,” JPMA. Elsevier Ltd and IPMA, 33(6), pp. 1335-1346. doi: 10.1016/j.ijproman.2015.02.008.

Pedro, J., Silva, C. and Pinheiro, M. D. (2018) “Scaling up LEED-ND sustainability assessment from the neighborhood towards the city scale with the support of GIS modeling: Lisbon case study," Sustainable Cities and Society. Elsevier, 41(September), pp. 929-939. doi: 10.1016/j.scs.2017.09.015.

Säynäjoki, E. et al. (2012) “An assessment of the applicability of three international neighbourhood sustainability rating systems to diverse local conditions, with a focus on Nordic case areas," International Journal of Sustainable Building Technology and Urban Development, 3(2), pp. 96-104. doi: 10.1080/2093761X.2012.696319.

Shari, A. and Murayama, A. (2014) "Neighborhood sustainability assessment in action : Cross-evaluation of three assessment systems and their cases from the US , the UK, and Japan,” 72. doi: 10.1016/j.buildenv.2013.11.006. 
Sharifi, A. (2013) "Sustainability at the neighborhood level: assessment tools and the pursuit of sustainability," (March), p. 233. Available at: https://nies.academia.edu/AyyoobSharifi.

Sharifi, A. et al. (2016a) "From Garden City to Eco-urbanism: The quest for sustainable neighborhood development," Sustainable Cities and Society. Elsevier B.V., 29(5), pp. 291-299. doi: 10.1016/j.scs.2015.09.002.

Sharifi, A. et al. (2016b) "From Garden City to Eco-urbanism: The quest for sustainable neighborhood development," Cities. Elsevier B.V., 29(5), pp. 291-299. doi: 10.1016/j.scs.2015.09.002.

Sharifi, A. and Murayama, A. (2013) "Changes in the traditional urban form and the social sustainability of contemporary cities: A case study of Iranian cities," Habitat International, 38, pp. 126-134. doi: 10.1016/j.habitatint.2012.05.007.

Sharifi, A. and Murayama, A. (2014) "Neighborhood sustainability assessment in action: Cross-evaluation of three assessment systems and their cases from the US, the UK, and Japan,” Building and Environment, 72, pp. $243-258$. doi: 10.1016/j.buildenv.2013.11.006.

Sharifi, A. and Murayama, A. (2015) "Viability of using global standards for neighbourhood sustainability assessment: insights from a comparative case study," Journal of Environmental Planning and Management. Taylor \& Francis, 58(1), pp. 1-23. doi: 10.1080/09640568.2013.866077.

Shen, Z. (2012) Advances in Geographic Information Science. doi: 10.1007/978-3-642-05299-6.

Sullivan, L., Rydin, Y. and Buchanan, C. (2014) "Neighbourhood sustainability frameworks-a literature review," (May), p. 22. Available at: http://discovery.ucl.ac.uk/1428696/. 
Tam, V. W. Y. et al. (2018) "Green neighbourhood : Review on the international assessment systems," Renewable and Sustainable Energy Reviews. Elsevier Ltd, 82(2017), pp. 689-699. doi: 10.1016/j.rser.2017.09.083.

Tsai, C. C. and Wen, M. L. (2002) “International Journal of Science Research and trends in science education from 1998 to 2002 : a content analysis of publication in selected journals," (2014), pp. 37-41. doi:

10.1080/0950069042000243727.

Tsai, T. A. (2014) “Accessibility with Community Empowerment Programs,” pp. 2766-2785. doi: $10.3390 /$ su6052766.

USGBC (2009) “LEED 2009 for Neighborhood Development Rating System Created by the Congress for the New Urbanism, Natural Resources Defense Green Building Council ( Updated May,” (October 2010).

“WCED” (1987) World Commission and Environment and Development, 17.

Yigitcanlar, T., Kamruzzaman, M. and Teriman, S. (2015) "Neighborhood sustainability assessment: Evaluating residential development sustainability in a developing country context," Sustainability (Switzerland), 7(3), pp. 25702602. doi: 10.3390/su7032570.

Zhang, Q. et al. (2018) “Towards Sustainable Neighborhoods : Challenges and Opportunities for Neighborhood Planning in.” doi: 10.3390/su10020406.

Zhang, X., Cheng, J. and Wu, S. (2010) “Evaluating community accessibility for sustainable urban regeneration : a conceptual framework," Green Manufacturing, pp. 444-456. 